\title{
Irresponsibility through Corporate Eyes: Reporting of Human Rights Compliance by Spanish Listed Companies
}

\author{
Marta de la Cuesta \\ Facultad de Económicas y Empresariales de la UNED \\ C/ Senda del Rey 11, 28040, Madrid, Spain
}

Tel: 34-91-398-6354 E-mail: mcuesta@cee.uned.es

Carmen Valor

Universidad Pontificia de Comillas ICADE

Alberto Aguilera 23, 28015, Madrid, Spain

Tel. 34-91-542-2800 Ext. 2291 E-mail: cvalor@upcomillas.es

\author{
Pablo Holgado \\ Facultad de Psicología de la UNED \\ C/ Juan del Rosal 10, 28040, Madrid, Spain
}

Tel: 34-91-398-8430 E-mail: pfholgado@psi.uned.es

$\begin{array}{ll}\text { Received: October 18, } 2011 & \text { Accepted: November 9, 2011 Published: February 16, } 2012 \\ \text { doi:10.5539/ijbm.v7n4p69 } & \text { URL: http://dx.doi.org/10.5539/ijbm.v7n4p69 }\end{array}$

\begin{abstract}
Corporate compliance with human rights has received little attention in the management literature. This papers aims to shed some light on this issue, by examining business recognition of Human Rights; in particular how companies state their own commitment with the Human Rights; the policies and procedures in place to ensure compliance, including mechanisms of control and enforcement; and corporate performance vis-à-vis human rights. Corporate Social Responsibility reports of Spanish IBEX-35 companies were used as the main source of information. We conclude that companies have, at most, a formal commitment to certain human rights (labour, consumer protection and environment). External drivers such as financial markets and reputational hazards are keys to explain differences among companies.
\end{abstract}

Keywords: Human Rights, Compliance, Spain, Corporate Social Responsibility

\section{Introduction}

Corporate compliance with human rights has received little attention in the management literature. Most papers examine the issue from a legal point of view, rather than seeing it as a managerial issue. It has been established that human rights, as detailed in the Universal Declaration adopted in 1948 by the United Nations, represent a global normative framework for all organisations, given that they are regarded as core values applicable to all religions and cultures (Bishop, 2008; Carasco and Singh, 2008). In addition, non-state actors (such as Amnesty International or the Centre for Business and Human Rights) have also campaigned to hold corporations accountable to human rights standards (Chandler, 2009; Sullivan, 2003; Watts, 2005). Also, respect for human rights is the most used criterion by responsible consumers and investors to guide their economic decisions (Ruggie, 2008a). Therefore companies, and especially transnational corporations, are de iure and de facto obliged to, at least, respect the Universal Declaration of Human Rights (Schouten, 2007).

However, scant research has been done on whether companies observe human rights. Two studies conducted by United Nations (Ruggie, 2006a and 2006b) shed some light on the practices of corporation vis-à-vis human rights. Yet, as Schouten (2007) remarks "there is no comprehensive overview of the extent of human rights violations by business", except those conducted by NGOs and watchdog organisations websites; these are not aimed to be scientific but to make public corporate violations of human rights in their spheres of influence. At 
most, there have been case studies for specific industries and/or specific rights (Watts, 2005).

This paper tries to fills this gap by analysing Spanish business recognition of human rights and verifying whether this recognition is put into practice. This is of utmost importance since human rights are regarded as hypernorms (Bishop, 2008); thus, violations are seen as the worst irresponsibility. To our knowledge, this issue has not been object of research; at most, some papers have examined compliance with labour rights (e. g. Kolk and Van Tulder, 2002; Urminsky, 2005), especially in supply chains (e.g. Holder-Webb et al., 2009).

\section{Normative status of corporate human rights responsibility}

There is no global agreed framework for human rights and companies, either voluntary or mandatory (Ruggie, 2006b). International Declarations - such as the those illustrated in table 1 - have established the responsibility of companies to respect human rights (Riesenfeld, 2008; Schouten, 2007; Ssenyonjo, 2008; Weissbrodt, 2005), but have not elaborated further on the extent of this obligation or the consequences in case of non-compliance. As Wouters and Chanet (2008) remark, international legislation is rather unbalanced, given that it protects corporations' rights but does not recognise their responsibilities.

At the national level, both US and the EU have regulation enabling to bring companies to the national courts where they are domiciled for violations of human rights elsewhere (Aliens Tort Act and Brussels I Regulation) (for specific analysis of these instruments, see Chanin, 2005; Wouters and Chanet, 2008).

Currently, there is a preference for soft law instruments, i.e., codes of conduct. Yet, most authors contend that, given the growing power of corporations, there is a need for global legally binding instruments to ensure that firms respect and make respect human rights (Riesenfeld, 2008; Schouten, 2006), or, at least, to address the worst cases of violations of human rights (Wouters and Chanet, 2008).

Codes of conduct are the natural instrument for corporate control under the business case for corporate social responsibility (CSR hereafter) (Cuesta de la and Valor, 2004; Michael, 2007). The business case has become a framework orienting the definition and implementation of CSR. The business case contends that self-regulation will work because companies have enough market incentives to behave responsibly. Whilst some authors (e.g. Chanin, 2005; Vogel, 2005) have argued against the existence of such arguments, others have waived a moral argument against the economic motivation for CSR, in these terms. The economic motivation cannot be the ultimate reason: companies should comply with Human Rights because they have to, not because it is profitable to do so (Wouters and Chanet, 2008). Human rights should be regarded as hypernorms, applying prior to the law: firms must not violate them, whether or not they are recognised in national laws (Bishop, 2008), or whether or not this impacts positively the bottom-line (Wouters and Chanet, 2008).

This is a controversial but a key issue from a conceptual point of view. If we accept that companies are legally forced to observe human rights, then HR cannot be considered part of CSR, as CSR is defined as going beyond compliance (Barth and Wolff, 2009). Therefore the business case argument cannot be invoked and codes of conduct should not be favoured as the best instrument to ensure compliance with Human Rights.

A handful of codes of conduct have included respect for human rights in the set of obligations that companies voluntarily should assume (Weissbrodt, 2005). Some mention all human rights (e.g. Global Compact; OECD Guidelines) whilst others refer to a subset of them (see table 1 and a review of existing codes in Carasco and Senghi, 2008 and Schouten, 2007).

There is a specific initiative dealing with firms and human rights: the UN Norms on the Responsibility of Transnational Corporations and Other Business Enterprises with Regard to Human Rights (UN Norms, hereafter). A previous attempt by the UN to produce a code on human rights (the UNCTC Draft Code) was unsuccessful (Carasco and Singh, 2008; Schouten, 2008).

The Sub Commission on the Promotion and Protection of Human Rights approved the Norms in 2003, after six years of debates and consultation with states, corporations and international organisations. The Norms acknowledge that states have the primary responsibility for the protection of human rights, but it also places responsibility on companies to respect and ensure respect of human rights. The UN Norms have eventually been abandoned by the Sub Commission, due to the strong opposition of the business community (see Martín-Ortega, 2008 and Riesenfeld, 2008, for a review of the history of the Norms) and the personal decision of the Secretary General's Special Representative for Business and Human Rights (SRSG), who has proposed the "Protect, respect and remedy" framework instead. Yet, the Norms have several advantages over other codes (Carrasco and Singh, 2008; Riesenfeld, 2008; Weissbrodt, 2005).

First, they are fairly comprehensive, given that they encompass the following issues: right to equal opportunity and non-discriminatory treatment; right to security of persons; right of workers; respect for national sovereignty 
and human rights; obligations with regard to consumer protection; and obligations with regard to environmental protection. Besides, since they command companies to respect human rights in their "spheres of activity and influence", they apply to suppliers and subsidiaries (Riesenfeld, 2008). Second, they are legitimate, given that they are based on previous UN Declarations, accepted by the majority of countries.

Third, although they are not legally binding, they were not conceived to be purely voluntary either. The other codes are voluntary and do not have monitoring and enforcement mechanisms, which is seen as their main limitation for corporate control (Watts, 2005). The Norms devise several implementation mechanisms. On the one hand, it urges states to "establish and reinforce the necessary legal and administrative framework for ensuring that the Norms and other relevant national and international laws are implemented by transnational corporations and other business enterprises (a. 17)". On the other hand, apart from establishing their own systems to ensure compliance, firms are required to perform self-evaluations and third-party monitoring, to record claims of violations, to incorporate the principles into contracts, and to provide reparation.

The Norms are considered a form of soft law, and as such, they could provide the basis for international law (Carasco and Singh, 2008). Yet, as they are not a treaty, there are no penalties in case of non-compliance or in case of failure to implement the requirements of the Norms.

\section{Human rights as a managerial issue}

Insert Table 1- here

The previous section has shown that there is a global agreement that companies, and especially transnational corporations, are expected to observe the Declaration of Human Rights (HR hereafter). Therefore, companies should develop policies and procedures to ensure respect for human rights, in cooperation with other stakeholders (namely, NGOs, trade unions and international governmental organisations) (Schouten, 2007). Few researchers have proposed such managerial frameworks (Jackson, 2008; Shouten, 2007). Ruggie's report "Protect, respect, and remedy" (Ruggie, 2008a and 2009) offers some guidelines to companies: engage in due diligence process to assess the risk of human rights abuse; develop detailed policies, offering guidelines to functional areas; conduct impact assessments prior to investing in new projects; implement monitoring and auditing process to track performance.

On the business side, several companies joined in the Business Leaders Initiative on Human Rights (http://www.blihr.org/), whose mission is to find "practical ways of implementing the Universal Declaration of Human Rights in a business context". Sixteen companies belong to this initiative, a tiny fraction of total TNCs. Through a series of meetings, they have created guidelines and instructions for companies to ensure respect for HR in their spheres of influence. Also, guidelines can be found in the Global Compact website and in the UN site created to foster corporations' compliance with human rights.

As to the practice of "HR observation", as we said in the Introduction, few papers have examined the issue. The best (and practically only) source of information is the so-called "Ruggie reports". Ruggie and his team conducted three research projects. First, they surveyed Fortune500 companies through an online questionnaire (valid sample of 102 companies), about their existing policies and initiatives towards HR compliance (Ruggie, 2006a). Second, they analysed corporate information in order to identify salient human rights, initiatives to promote HR in their spheres of influence, and accountability mechanisms (Ruggie, 2006b). Finally, they examined the cases posted on the Business and Human Rights Resource Centre to identify the scope and patterns of corporate abuse of HR (Ruggie, 2008b). Apart from the SRSG's work, the Global Compact Annual Review section on HR offers some hints on the policies signatories have implemented to ensure compliance with Principles 1 and 2.

These studies highlighted that large companies have an explicit human rights principles declaration, usually in their codes of conduct. Labour rights, those defined as core by the ILO, enjoyed the highest level of recognition, especially in Europe and North America. Companies seem less aware of non labour rights, especially outside Europe and North America. Among non-labour rights, the right to privacy is the most frequently mentioned, especially by European companies. Therefore, not every right is equally salient to companies. Companies tend to identify which rights are "relevant to their business operations and [devise] their policies accordingly" (Ruggie, 2006a: 8).

As regards implementation, there are wide differences among companies. A limited number of companies conduct HR impact assessments (Ruggie, 2006a) and few provide external assurance (Ruggie, 2006b). The same can be said regarding implementation of HR in their supply chains (Ruggie, 2006b). Taking into account Ruggie's office findings, we can conclude that companies are still at the "inspiration" stage (Waddock et al, 2007) in their responsibility management systems for human rights protection, given that they have only started to 
make explicit their commitment but have not established policies and plans that have yielded results, especially as regards their supply chain. This "makes it difficult for the company itself, let alone the public, to measure performance against commitments" (Ruggie, 2006b: 57).

Also companies are encouraged to report how they observe HR in their spheres of influence. The Global Reporting Initiative (GRI) promotes reporting on HR performance. GRI is the most widely framework for non-financial reporting (Context, 2006; Hedberg and von Malmborg, 2003; KPMG, 2008; Sustainaibility, 2004). The latest version of its guide (GRI3) includes 9 indicators on human rights (see table 1). These indicators cover a marginal fraction of the requirements contained in the UN Norms, given that companies only have to report on core labour rights (which could explain why these rights have the highest level of recognition) and on the use of HR in their operations. Corporate behaviour with indigenous communities and security practices although they have been a central problem for certain industries (e.g. extractive industries) are labelled as additional indicators.

It is of utmost importance that companies report on this issue, given that access to information is a precondition for the business case to work (Valor, 2008). Yet, this condition is far to being met. According to a study conducted by the ILO on labour rights (Urminsky, 2005), "levels of disclosure decrease for most variables as one move from policies to processes to performance. Thus more useful information such as performance data is often the least frequently reported on". This presents a potential risk for "corporate spin" (Doane, 2002), given that companies avoid reporting negative results whilst highlighting irrelevant, positive results.

Specifically regarding human rights, several studies (Joseph, 2002; Leighton et al., 2002; Context, 2006; Corporate Register and ACCA, 2004; Urminsky, 2005) have found that companies tend to disregard human rights in their corporate reports, although this is what stakeholders want to read about (Pleon, 2005). Ruggie (2006b) states that the problem is that the information is "buried in complex websites, thereby limiting the effectiveness of reporting for internal as well as external purposes".

Another problem with corporate reports is misrepresentation. A minority of reports are verified by a third party (Context, 2006; KPMG, 2008; Ruggie, 2006b). Hence, readers cannot be sure whether the information disclosed is entirely true. In the EU, the Unfair Commercial Practices Directive prohibits misleading information if "it materially distorts or is likely to materially distort the average consumer's economic behaviour with regard to the product" (article 2(b)). The Directive has specifically prohibited that companies include misleading information about their adherence to codes of conduct or about the characteristics of these codes of conduct. Hence, this Directive is a mechanism to seek for redress if an issue is misrepresented in corporate reports. However enforcement mechanisms of this directive vary greatly across EU members and are not as efficient as they should (Wouters and Chanet, 2008).

\section{Objectives and methodology}

This papers aims at examining business recognition of HR; in particular it will examine how companies state their own commitment with the HR; the policies and procedures in place to ensure compliance, including mechanisms of control and enforcement; and the degree of compliance with HR. To do so, we analysed public company-issued information on human rights (CSR or sustainability reports; codes of conduct; policies and other documents). These have been the primary source of information of previous studies (Ruggie, 2006b; Global Compact Annual Review, 2009), which will allow us to make comparisons with other regions. Given that at the time of collecting the data not every company had produced the 2008 CSR Reports, we used the 2007 documents, in order to have a homogenous basis for comparison.

\subsection{Sample selection}

The 35 companies listed in the IBEX-35 index on the $31^{\text {st }}$ December 2007 were selected. These are the companies with the largest capitalisation; most of them being transnational corporations. HR are believed to be more salient for multinational companies given that issues in HR arise due to governance gaps created in the course of globalisation (Ruggie, 2008a). Companies on this index belong to the main activity sectors in the Spanish economy. Besides, these companies are considered at the avant-garde in CSR (as well as in other strategic issues) and they all publish CSR reports; thus, other companies usually use them as a benchmark. Therefore, although they are not representative of the entire Spanish business universe, IBEX-35 companies are frequently used to get an insight into the status and trends of CSR among Spanish companies (García de Madariaga and Valor, 2006).

\subsection{Variables and scoring system}

UN Norms were selected as the main framework to evaluate HR performance. No previous study has examined corporate compliance with the UN Norms, although they are the most developed voluntary initiative to create a 
common framework of firm responsibilities as regards human rights. Furthermore, managerial frameworks (such as those developed by BLIHR or UN Global Compact) are grounded on the Norms. UN Norms include, but exceed, the requirements found in GRI version 3 guide. Given that they compile the main international regulatory initiatives on human rights (inter alia, indigenous communities rights, corruption, childhood rights, labour rights, consumer rights), the Norms constitute the most comprehensive and legitimate benchmark to evaluate corporate performance.

A list of indicators or items was created from the UN Norms. Each of the articles/rights was transformed into a set of indicators, capturing each one an obligation of the firm as stated in the article. To structure these indicators, the sections of the Norms were followed. In total, 99 indicators were used to evaluate compliance with HR. It could be argued that other corporate practices create the right environment for human rights protection (paying taxes or creating employment) (Schouten, 2007). Yet, since we focus specifically on human rights compliance, it goes beyond the scope of this paper to analyse the influence of these facilitating variables.

Apart from the indicators listed in Table 2, we also codified the countries of operation (whether a firm operates only in OECD or in OECD and non-OECD countries) and industry (following the industry categories of the Spanish stock market), which have been found key to explain differences in corporate policies regarding human rights (Ruggie, 2006a and 2006b). In addition, differences were explored between companies listed in foreign stock markets, those listed in sustainability indexes, and those who were not. Finally, we used market capitalization at December 2007 (less than 10 million€; between 10 and 50 million $€$; and greater than 50 million $€)$.

The indicators were valued using a 4-point Likert scale $(0=$ no information; $1=$ anecdotal information; $2=$ incomplete information (limited to certain countries or business units); $3=$ complete information).

A team of 8 analysts reviewed the CSR reports and evaluated the companies. To minimise subjectivity, several strategies were used: analysts took part in a training session; weekly meetings were held to homogenize criteria and solve doubts when evaluating companies; the same analyst reviewed reports of companies in the same industry. Also, the final report was reviewed by the analysts to increase reliability.

\section{Insert Table 2- here}

The indicators were incorporated into a SPSS file, and analysed using statistical techniques. Given that this is the first study to operationalize the UN Norms in a study of corporations, we thought it would be necessary to obtain empirical evidences about the reliability, discrimination, and validity of the variables used. Several analyses were conducted in order to understand how companies report compliance with HR. In addition to univariable analyses, t-tests (ANOVA or Kruskal-Wallis tests when variables did not have equal variances) were carried out to find out whether differences could be found taking into account the industry, the countries of operation, the market capitalization, and the listing in foreign stock markets/sustainability indexes.

\section{Results}

\subsection{Reliability and validity analysis of the instrument used}

Alpha coefficients range from 0.825 for Rights to life, liberty and security, and 0.959 for National Sovereignty. Given that each dimension got a coefficient greater than 0.80 we can conclude that the variables were reliable for the purpose of this study (Devellis, 1993; Nunally, 1991).

In addition, all the items show good discrimination capacity; in three dimensions (Formal commitment and disclosures, Consumer Protection and Environment) no item was removed. Some items in other dimensions were removed if their discrimination was lower than 0.3. In all, few items were removed (see Figure 2). The discrimination ranged from 0.522 for Consumers protection to 0.77 for National Sovereignty. The average discrimination was greater than 0.30 , which is considered acceptable (Nunnally and Bernstein, 1994).

Also, the criterion validity was analysed by using the point-biserial correlation. The criterion used for this analysis was whether or not the firm was listed in sustainability indexes (FTSE4 Good, FTSE4Good Environmental Leaders Europe 40 Index, Dow Jones sustainability, KLD Global Climate 100 Index, ASPI, S\&P Global Clean Energy Index and Ethibel Sustainability Index). The point-biserial correlation was 0.83, which is considered acceptable (Nunnally and Bernstein, 1994). Table 3 summarizes the findings.

\subsection{Description of information reported}

Insert Table 3- here

\subsubsection{Formal commitment and disclosures}

Human rights compliance is not a priority in the corporate agenda: most companies have an informal or 
nonexistent commitment towards human rights. Moreover, disclosures are more oriented to list the treaties and codes they are committed to, rather than showing evidences of compliance: no company shows evidence of performance in their corporate information. This is not surprising, given that only a handful of companies (7) report having management systems in place regarding human rights. Without these management systems, it will prove difficult to ensure compliance with treaties and codes.

\subsubsection{Rights to life, liberty and security}

This is one of the human rights of lessen importance, according to corporate information. Only two companies give information of their management systems designed to avoid being accomplices of violations of humanitarian law.

Limited information is given also to the issue of forces of security. Only three companies explain their obligations regarding this matter. Seven more explain how they introduce human rights in their contracts with private security forces. Again, providing evidences of performance is rare: only one company says to have verified compliance.

\subsubsection{Rights of workers}

Labour rights are, by far, the issue about which more companies report. However, disclosures are very different across specific rights. Fair salary and collective negotiation rights are the ones with the fewest mentions: companies do not even formally recognize these rights. These are followed by forced labour and child labour in the supply chain: less than one third of companies given information about these rights. In contrast, discrimination is widely recognized (only four companies fail to mention it in their corporate information).

However, few companies provide complete information about their management systems. Only four companies explain their local health and safety procedures and systems; three companies (BBVA, ENDESA and Repsol YPF) explain the procedures in place to ensure compliance with the non-discrimination principle; two, to avoid forced labour. Scores are even lower when we analyse whether companies are showing performance. The highest score is given to non-discrimination, where four companies (Iberdrola, Gas Natural, REE, Repsol YPF) disclose information of salaries by gender and by professional status, which is an indication of compliance. Also, as regards fair salary, two companies give evidence that they are complying with this right.

\subsubsection{National Sovereignty}

Economic, social and political rights receive considerably less attention than labour rights. Few companies (7) report how they observe the norms protecting civil and political rights. Even these companies give anecdotal information that does not allow to evaluate whether they are actually respecting these rights in their spheres of influence. No company acknowledges its commitment to respect or explain how they observe cultural and social rights in the countries where they operate.

Six companies commit themselves to foster the economic and social development of the countries where they have operations. Yet, no company has a commitment to respect the right of any community to have access to food, shelter, and safe water and no company has a clear commitment to respect national sovereignty in all countries of operation.

As regards indigenous peoples, only 4 companies mention this issue on their reports but none of them have a straight and clear commitment to respect their rights and do not offer clear evidence of treating indigenous peoples fairly and with integral respect for their dignity.

\subsubsection{Corruption}

Approximately half of the IBEX-35 companies give some information about they include corruption and bribes in their codes of conduct. Still, the quality of this information varies greatly across companies: only 6 companies clearly explain what kind of auditing and certification procedures they follow to avoid fraud in their financial statements. Information about prevention is scarcer: only 4 companies explain how they avoid corruption in their spheres of influence. The same can be said about money laundering, given that only 6 companies explain how they fight against this kind of criminal activity.

As regards management systems, information is rather fragmented and poor. No company gives a precise description of the systems in place to manage and prevent corruption. Only three companies give some explanation on how they try to avoid internally acts leading to obstruction of justice and how they cooperate with public officials in corruption-related issues. Two companies have a clear commitment to and explain how they try to prevent influence peddling in their spheres of influence and only two explain what kind of systems they have in place to ensure it. Finally, five companies explain how they warrant protection to witnesses and 
"whistleblowers" in cases of corruption.

\subsubsection{Consumers protection}

Together with labour rights, these are the human rights about which firms report more information. Still, the disclosures refer more to formal commitments, rather than management systems and, least of all, performance. Even regarding formal commitments, information varies greatly across rights. While rights to enjoying safe products are said to be respected by nearly all firms, only a third of the sample explicitly commits to avoid untrue or false advertising, and only one obligates itself not to use abusive commercial practices.

Here, the pattern followed for the other rights occurs as well. Approximately half of the sample gives some information about systems in place to ensure protection of consumers' rights (especially quality management systems and safety systems), information on performance is scant: only one company report the number and types of violations of these rights and the sanctions inflicted in each country of operation.

Also, companies do not exhibit a proactive stance in relation to consumers' education and sustainability: twelve companies engage in initiatives aimed at educating and informing consumers on not-brand specific issues; less than a third of the sample express their responsibility to promote sustainable ways of consumption.

\subsubsection{Environment}

Most companies give some information on plans and initiatives aimed at fostering sustainable development. Half of the sample report how they comply with international and national laws regarding environment, public health and bioethics. However, information about performance is again rare: only 9 companies report evaluating periodically the influence of their operations on the environment and human health, although no company acknowledges distributing these evaluations among affected parties and explicitly assumes responsibility for the damages inflicted on the environment and human health as a result of their activities.

\subsubsection{Provisions for implementation}

Few companies (8) report how they implement systems to observe human rights in all the countries where they operate but no company conducts periodic evaluations of their compliance of human rights. Only two companies explain their training and teaching programs in human rights and report monitoring the consequences that their activities and operations may have on human rights. Four companies acknowledge using human rights in their contracts with third parties (procurement or investment projects).

\subsection{Different approaches to human rights}

To explore differences in the sample, ANOVA and K-W tests were conducted. It is important to bear in the mind that sample size may have led not to find significant differences between cases. We find that there are significant differences by industry in the Environment dimension $\left(\mathrm{F}_{(4,29)}=371\right.$; $\mathrm{p}$-value $\left.=0.015\right)$, the energy industry having greater scores than raw materials, and consumer goods. Also, in Consumer Protection (Kruskal-Wallis test = 13.84; $\mathrm{p}$-value $=0.007)$ there are differences between energy and raw materials, being higher the scores for the energy industry. Therefore, we conclude that the energy industry report higher level of compliance as regards the Environment and Consumer Protection than other industries. Even when differences are not significant, the following figure shows that the Energy have a higher level of performance in all dimensions except National Sovereignty. It is also remarkable that the Finance firms exhibit a higher level of performance in Corruption than the other industries (except Energy). Raw material is by far the industry with the lowest levels of performance.

\section{Insert Table 4- here}

Insert Figure 1- here

Yet, in relation to foreign stock markets, there are significant differences in all dimensions except in Formal commitment and disclosures. For all dimensions of human rights, listed companies in foreign markets have a greater level of compliance than non-listed firms (Life, liberty, security Kruskal-Wallis test $=9.81$; p-value $=0.001$; Labour Rights $\mathrm{F}_{(1,32)}=8.51$, p-value $=0.006$; Corruption $\mathrm{F}_{(1,32)}=27.28 ;$ p-value $=0.000$; National Sovereignty $\mathrm{F}_{(1,27)}=6.08 ; \mathrm{p}$-value $=0.02$; Environment Kruskal-Wallis test $=5.66$; $\mathrm{p}$-value $=0.017$; Consumer protection $\mathrm{F}_{(1,32)}=5.89$, p-value $=0.021$; Implementation $\mathrm{F}_{(1,32)}=7.12$, $\mathrm{p}$-value $=0.012$ ).

\section{Insert Figure 2- here}

No significant differences are observed according to the countries of operation, although scores in the dimensions Labour, Corruption and Consumers Protection were higher for companies operating in OECD and non-OECD countries.

In contrast, differences were observed according to the variable "market capitalization". All dimensions except 
Formal Commitment and Life, liberty and security exhibit significant differences (Labour Rights $\mathrm{F}_{(2,31)}=7.75$, $\mathrm{p}$-value $=0.002$; Corruption $\mathrm{F}_{(2,31)}=11.53, \mathrm{p}$-value $=0.000$; National Sovereignty $\mathrm{F}_{(2,31)}=14.76, \mathrm{p}$-value $=0.000$; Environment $\mathrm{F}_{(2,31)}=5.63$, p-value $=0.008 ;$ Consumer protection $\mathrm{F}_{(2,31)}=8.55, \quad \mathrm{p}=0.001 ;$ Implementation Kruskal-Wallis test $=9.52$; p-value $=0.008$ ). Post-hoc analysis (Scheffé) show that differences are significant between the lowest and highest market capitalization in Labour rights, National Sovereignty, and Environment, being higher the compliance level of companies with a higher market capitalization. In addition, there are significant differences between firms with high and mid capitalization, in Corruption and Consumers Protection, being also higher the scores for companies with high capitalization.

\section{Insert Figure 3- here}

Finally, there are significant differences between companies listed and not listed in CSR indexes, in all dimensions except National Sovereignty (Formal Commitment $\mathrm{F}_{(1,31)}=12.34$, p-value $=0.001$; Life, liberty, security Kruskal-Wallis test $=4.81$; $\mathrm{p}$-value $=0.028$; Labour Rights $\mathrm{F}_{(1,32)}=22.39$, $\mathrm{p}$-value $=0.000$; Corruption Kruskal-Wallis test=11.20; p-value $=0.0008$; Environment $\mathrm{F}_{(1,32)}=8.18$, p-value $=0.007$; Consumer Protection $\mathrm{F}_{(1,32)}=24.87$, $\mathrm{p}$-value $=0.000 ;$ Implementation $\mathrm{F}_{(1,32)}=6.67$, $\mathrm{p}$-value $=0.015$ ).

\section{Insert Figure 4- here}

\section{Conclusions}

Compliance with human rights is a material or hot topic for every company, given that they are considered hypernorms, thus, a core normative framework for any organization. However, this study has evidenced that the issue is not on the agenda of the largest Spanish companies. These companies are considered in the leaders in CSR. Therefore, we can anticipate that the degree of relevance of this issue for non-IBEX companies is still lower. There is an enormous gap between stakeholders' claims and corporate strategy. This gap should be addressed or companies may encounter problems in the future, given that the risks of non-compliance are higher.

Most of the analysed companies are at the inspiration stage: they have made a formal commitment to comply with human rights but have not devised a management system to ensure compliance. Companies are not approaching human rights from a managerial perspective. This increases the risks of non-compliance, which would have legal and reputational consequences for firms.

Companies in the sample have established a vague, general, formal commitment with human rights, frequently by adopting the Global Compact. The results show that companies have not made specific commitments to all the rights included in the UN Norms. Also, they do not spread their commitment throughout their business units and affiliates at different locations. As previous studies have found, companies tend to focus on Labour rights, followed by Consumers protection, and Environment. Other dimensions of human rights such as Life, Liberty and Security, Corruption, or National Sovereignty are hardly considered by the sampled companies.

Even companies operating in OECD countries do not show evidences of compliance with rights incorporated in regulation (e.g. Labour Rights, Consumer Rights and Environment Rights). Scores in Consumer protection, Corruption or Environment are low (less than 30\% of the scale), even in industries where these rights are key, such as Consumer goods or IT, Finance, or Raw Materials, respectively. Therefore, this study does not follow the conclusion of previous studies that found a correlation between rights and industry. In this study, there is not a clear pattern among firms; we cannot conclude that companies are trying to minimize the externalities associated with their business operations. Also, we cannot conclude that countries of operation are a key mediating variable, given that there are not significant differences between companies operating in OECD and in non-OECD countries, either regarding performance or implementation systems.

It is clear that the drivers for a better management of human rights are external. Two drivers emerge as key: financial markets and reputational hazard. Companies listed in foreign markets and those listed in CSR indexes exhibit higher levels of performance in all dimensions and better management systems. In addition, larger companies, companies operating in business to consumer markets, and companies in industries that have been a traditional target of activists (Energy, Consumer goods, and Finance) are the ones with the highest levels of performance.

Therefore, we can conclude that reputation management is a powerful driver to incorporate human rights into the agenda. As previous studies have shown (García de Madariaga and Valor, 2006), the CSR strategy of Spanish firms is oriented to being listed in sustainability indexes. They aim at attracting capital, but more important, at improving their reputation by being in these types of indexes. There is also a me-too effect among companies in the same industry, given that they compete to be listed in the same indexes or achieve better positions in rankings. This could explain why industry is a key mediating variable, rather than countries of operation. Companies do not plan 
their human rights strategy after a careful diagnosis of the local situation; rather, they follow the steps done by leaders in the industry.

It is of utmost importance to conduct more studies, in order to clarify contradictory findings between this and previous studies. To do so, the same benchmark should be used to compare companies, across countries and industries. The reliability and validity analyses of the instrument used in this study, based in the UN Norms, have shown that it is a satisfactory benchmark. The internal consistency of the scales and its discrimination power are adequate, as it is the criterion validity of the scale.

In Spain, the study should be replicated with a larger sample size to better explore differences among companies. This is a key procedure in order to understand the drivers for addressing human rights internally. Also, comparisons should be made across Europe and between EU companies and other non-European firms. Future studies should also contrast corporate information with actual information on compliance (e.g. reports sent to the Centre of Business and Human Rights). This will allow concluding whether the systems in place are effective, as well as examining the rhetoric and realities in CSR reports regarding human rights. In addition, it should also be examined the business case assumption that a better performance in HR could lead to better financial results.

Regarding the instrument, the dimensionality of the concept measured and how the dimensions are connected in a nomothetic network should be explored. This is especially relevant to build "causal" models that could help us to understand how social responsibility works in different business areas.

\section{Acknowledgments}

We are grateful to Observatorio de la RSC and SUSTENTIA for allowing us to use their CSR database for this paper.

\section{References}

Barth, R., \& Wolff, F. (2009). Corporate social responsibility and sustainability impact: opening up the arena. In Barth Regina and Wolff Francesca, (Eds.) Corporate social responsibility in Europe. Rhetoric and Realities (pp. 3-25). Cambridge: Edward Elgar.

Bishop, J. D. (2008). For-Profit corporations in a just society: a social contract argument concerning the rights and responsibilities of corporations. Business Ethics Quarterly, 18, 191-212.

Carasco E. F., \& Singh, J. B. (2008). Human rights in global business ethics codes. Business and Society Review, 113, 347-374. http://dx.doi.org/10.1111/j.1467-8594.2008.00324.x

Chandler, G. (2009). The amnesty international UK business group: putting human rights on the corporate agenda. The Journal of Corporate Citizenship, 33, 29-34.

Chanin, J. M. (2005). The regulatory grass is Greener: A comparative analysis of the alien tort claims act and the European Union's Green Paper on corporate social responsibility. Indiana Journal of Global Legal Studies, 12, 745-778. http://dx.doi.org/10.2979/GLS.2005.12.2.745

Context. Global corporate responsibility reporting trends. (2006) [Online] Available: http://www.econtext.co.uk/cover_scans/InContext2006.pdf (August 14, 2006).

Corporate Register and ACCA. Towards transparency. Progress on global sustainability reporting 2004, [Online] Available: www.corporateregister.com/pdf/TowardsTransparency.pdf (August 14, 2006).

Cuesta, M. De la., \& Valor, C. (2004). Fostering corporate social responsibility through public initiative: from the EU to the Spanish case. Journal of Business Ethics, 55, 275-29. http://dx.doi.org/10.1007/s10551-004-0994-y

Devellis, R. E. (1991). Scale development: Theory and applications. New York: Sage.

Directive 2005/29/EC of the European Parliament and of the Council of 11 May 2005 concerning unfair business-to-consumer commercial practices in the internal market and amending Council Directive 84/450/EEC, Directives 97/7/EC, 98/27/EC and 2002/65/EC of the European Parliament and of the Council and Regulation (EC) No 2006/2004 of the European Parliament and of the Council ('Unfair Commercial Practices Directive').

Doane, D. (2002). Market failure: the case for mandatory social and environmental reporting. New Economics Foundation Publications. [Online] Available: http://www.hapinternational.org/pool/files/doanepaper1.pdf (August 14, 2006).

García de Madariaga, J., \& Valor, C. (2006). Stakeholders Management Systems: Empirical Insights from Relationship Marketing and Market Orientation Perspectives. Journal of Business Ethics, 71, 425-239. http://dx.doi.org/10.1007/s10551-006-9149-7 
Hedberg C. J., \& von Malmborg, F. (2003). The global reporting initiative and corporate sustainability reporting in Swedish companies. Corporate Social Responsibility and Environmental Management 10, 153-164. http://dx.doi.org/10.1002/csr.038

Holder Webb, L., Cohen, J., Nath Leda, R., \& Wood, D. (2009). The supply of corporate social responsibility disclosures among U.S firms. Journal of Business Ethics, 84, 497-527. http://dx.doi.org/10.1007/s10551-008-9721-4

Jackson, K. (2008). Natural law, human rights and corporate reputational capital in global governance. Corporate Governance, 8, 440-455. http://dx.doi.org/10.1108/14720700810899185

Joseph E. (2002). Promoting corporate social responsibility. New Economy, 9, 96-101. http://dx.doi.org/10.1111/1468-0041.00250

Kolk, A., \& Van Tulder, R. (2002). The effectiveness of self-regulation: corporate codes of conduct and child labour. European Management Journal, 20, 260-271. http://dx.doi.org/10.1016/S0263-2373(02)00043-9

KPMG. (2008). KPMG International survey of corporate responsibility reporting 2008, [Online] Available: http://www.kpmg.com/es/es/actualidadynovedades/articulosypublicaciones/paginas/survey-of-corporate-responsi bility-reporting-2008.aspx (September 10, 2009).

Leighton, M., Roht-Arriaza, N., \& Zarsky, L. (2002). Beyond deeds. Case studies and new policy agenda for corporate accountability. Natural Heritage Institute-Nautilus Institute for Security and Sustainable Development-Human Rights Advocates, California. [Online] Available: http://cloud2.gdnet.org/cms.php?id=research_paper_abstract\&research_paper_id=4099 (June 20, 2007).

Martín-Ortega, O. (2008). Business and human rights in conflict. Ethics \& International Affairs, 22, 273-283. http://dx.doi.org/10.1111/j.1747-7093.2008.00156.x

Nunnally, J. C. (1987). Psychometric theory. México: Trillas.

Nunnaly J. C., \& Berstein, I. (1994). Psychometric theory. New York: McGraw-Hill.

Pleon. (2005). Accounting for Good: the Global Stakeholder Report 2005. The Second World-wide Survey on Stakeholder Attitudes to CSR Reporting. [Online] Available: http://www.pleon.com/fileadmin/downloads/Pleon_GSR05_en.pdf (August 1, 2006).

Riesenfeld, S. A. (2008). Keynote address: international standard setting on the human rights responsibilities of businesses. Berkeley Journal of International Law, 26, 373-391.

Ruggie, J. G. (2006a). Human Rights Policies and Management Practices: Results from questionnaire surveys of Governments and Fortune Global 500 firms. United Nations High Commissioner For Human Rights, (A/HRC/4/35/Add.3). [Online] Available: http://198.170.85.29/Ruggie-survey-Fortune-Global-500.pdf (September 8, 2009).

Ruggie, J. G. (2006b). Business recognition of human rights: global patterns, regional and sectorial variations. United Nations High Commissioner for Human Rights, (A/HRC/11/13). [Online] Available: http://www2.ohchr.org/english/issues/trans_corporations/reports.htm (September 8, 2009).

Ruggie, J. G. (2008a). Protect, Respect and Remedy: a Framework for Business and Human Rights. United Nations High Commissioner for Human Rights (A/HRC/8/5). [Online] Available: http://www2.ohchr.org/english/issues/trans_corporations/reports.htm (September 8, 2009).

Ruggie, J. G. (2008b). Report of the Special Representative of the Secretary-General on the issue of human rights and transnational corporations and other business enterprises. United Nations High Commissioner for Human Rights (A/HRC/8/5/Add.2). [Online] Available: http://www2.ohchr.org/english/issues/trans_corporations/reports.htm (September8, 2009).

Ruggie, J. G. (2009). Business and human rights: Towards operationalizing the "protect, respect and remedy" framework. United Nations High Commissioner for Human Rights (A/HRC/11/13). [Online] Available: http://www2.ohchr.org/english/issues/trans_corporations/reports.htm (September 8, 2009).

Schouten E. M. (2007). Defining the corporate social responsibility of business from international law. Managerial Law, 49, 16-36. http://dx.doi.org/10.1108/03090550710759649

Ssenyonjo, M. (2008). The applicability of international human rights law to non-state actors: What relevance to economic, social and cultural rights? The International Journal of Human Rights, 12, 725-760. http://dx.doi.org/10.1080/13642980802396861 
Sullivan, R. (2003). NGO expectations of companies and human rights. Non-State Actors and International Law, 3, 303-322. http://dx.doi.org/10.1163/157180703322765111

Sustainability Risk \& Opportunity: Best Practice in Non-Financial Reporting. (2004). [Online] Available: http://www.sustainability.com/library/risk-opportunity (August 14, 2006).

Sustainability Tomorrow's value. The Global Reporters 2006 Survey of Corporate Social Reporting.(2006). [Online] Available: http://www.sustainability.com/library/tomorrow-s-value (December27, 2006).

UN. (2009). UN Norms on the Responsibility of Transnational Corporations and Other Business Enterprises with Regard to Human [Online] Rights. Available: http://www.unhchr.ch/huridocda/huridoca.nsf/(Symbol)/E.CN.4.Sub.2.2003.12.Rev.2.En United Nations Global Compact UN Global Compact Annual Review. http://www.unglobalcompact.org/docs/news_events/9.1_news_archives/2009_04_08/GC_2008AR_FINAL.pdf (September 8, 2009).

Urminsky, M. D. (2005). Public policy, reporting and disclosure of employment and labour information by multinational enterprises (MNES). Working Paper No. 99, International Labour Office. [Online] Available:http://training.itcilo.org/decentwork/staffconf2005/resources/session\%20VI/S6\%20WP99\%20MNEs\% 20disclosure.pdf (July 9, 2006).

Valor, C. (2008). Can consumers buy responsibly? Analysis and solutions of market failures. Journal of Consumer Policy, 31, 315-326. http://dx.doi.org/10.1007/s10603-008-9070-9

Waddock, S., Bodwell, C., \& Leigh, J. (2007). Total responsibility management. The manual. Sheffield: Greenleaf Publishing.

Watts, M. J. (2005). Righteous oil? Human rights, the oil complex, and corporate social responsibility. Annual Review of Environmental Resources, 30, 372-407. http://dx.doi.org/10.1146/annurev.energy.30.050504.144456

Weissbrodt, D. (2005). UN human rights norms for business. International Law FORUM du droit international, 7, 290-297. http://dx.doi.org/10.1163/157180405775268392

Wouters, J., \& Chanet L. (2008). Corporate human rights responsibility: A european perspective. Northwestern Journal of International Human Rights, 62, 262-303.

Table 1. Norms and codes of conduct regarding Human Rights

\begin{tabular}{|c|c|}
\hline \multicolumn{2}{|l|}{ Norms and declarations on Human Rights } \\
\hline Universal Declaration of Human Rights & http://www.un.org/en/documents/udhr/ \\
\hline $\begin{array}{l}\text { The International Convention on the Elimination of All } \\
\text { Forms of Racial Discrimination }\end{array}$ & http://www2.ohchr.org/english/law/cerd.htm \\
\hline International Covenant on Civil and Political Rights & $\begin{array}{l}\text { http://www.hrcr.org/docs/Civil\&Political/intlc } \\
\text { ivpol.html }\end{array}$ \\
\hline \multicolumn{2}{|l|}{ Mention Human Rights } \\
\hline Sullivan Principles (non discrimination and labour rights) & $\begin{array}{l}\text { http://www.thesullivanfoundation.org/about/g } \\
\text { lobal_sullivan_principles }\end{array}$ \\
\hline UN Global Compact & $\begin{array}{l}\text { http://www.unglobalcompact.org/docs/news_ } \\
\text { events/8.1/GC_brochure_FINAL.pdf }\end{array}$ \\
\hline OECD Guidelines & $\begin{array}{l}\text { http://www.oecd.org/document } / 28 / 0,3746 \text {,en } \\
\text { 2649_34889_2397532_1_1_1_1,00.html }\end{array}$ \\
\hline The Global Reporting Initiative (GRI) & $\begin{array}{l}\text { http://www.globalreporting.org/ReportingFra } \\
\text { mework/ReportingFrameworkDownloads/ }\end{array}$ \\
\hline \multicolumn{2}{|l|}{ Focused on business and Human Rights } \\
\hline $\begin{array}{l}\text { ILO Declaration for Multinational Enterprises (labour } \\
\text { rights) }\end{array}$ & $\begin{array}{l}\text { http://www.ilo.org/empent/Publications/WC } \\
\text { MS_094386/lang--en/index.htm }\end{array}$ \\
\hline $\begin{array}{l}\text { Voluntary Principles on Security and Human Rights } \\
\text { (security of persons) }\end{array}$ & $\begin{array}{l}\text { http://www.voluntaryprinciples.org/files/volu } \\
\text { ntary_principles_english.pdf }\end{array}$ \\
\hline $\begin{array}{l}\text { The UN Norms on the Responsibility of Transnational } \\
\text { Corporations and Other Business Enterprises with Regard to } \\
\text { Human Rights. }\end{array}$ & $\begin{array}{l}\text { http://www.unhchr.ch/huridocda/huridoca.nsf/ } \\
\text { (Symbol)/E.CN.4.Sub.2.2003.12.Rev.2.En }\end{array}$ \\
\hline "Protect, respect and remedy" framework & $\begin{array}{l}\text { http://198.170.85.29/Ruggie-protect-respect-r } \\
\text { emedy-framework.pdf }\end{array}$ \\
\hline
\end{tabular}


Table 2. Dimensions, variables and item

\begin{tabular}{|c|c|c|c|}
\hline $\begin{array}{l}\text { Dimension } \\
\text { (as specified in UN } \\
\text { Norms) }\end{array}$ & Variable & Content (number of indicators) & $\begin{array}{l}\text { UN } \\
\text { Norms } \\
\text { article }\end{array}$ \\
\hline \multirow{2}{*}{$\begin{array}{l}\text { Formal commitment } \\
\text { and disclosures }\end{array}$} & $\begin{array}{l}\text { Formal } \\
\text { commitment }\end{array}$ & $\begin{array}{l}\text { Commitment to respect HR; adherence to codes of } \\
\text { conduct, especially the UN Norms (4) }\end{array}$ & 1 \\
\hline & Disclosures & $\begin{array}{l}\text { Information on policies and procedures, and } \\
\text { performance with HR (2) }\end{array}$ & 1 \\
\hline \multirow{2}{*}{$\begin{array}{l}\text { Rights to life, } \\
\text { liberty and security }\end{array}$} & Humanitarian law & $\begin{array}{l}\text { Companies are not accomplices of violations of } \\
\text { humanitarian law (2) }\end{array}$ & 3 \\
\hline & Forces of security & $\begin{array}{l}\text { Internal forces of security comply with HR (3) } \\
\text { Private forces of security comply with HR (3) }\end{array}$ & 4 \\
\hline \multirow{6}{*}{ Right of workers } & Non-discrimination & Companies ensure equal opportunity (4) & 2 \\
\hline & Forced labour & $\begin{array}{l}\text { Companies will not use forced labour, directly or in } \\
\text { their productive chain, as forbidden in international } \\
\text { law (2) }\end{array}$ & 5 \\
\hline & Child labour & $\begin{array}{l}\text { Companies will not use child labour, directly or in } \\
\text { their productive chain, as forbidden in international } \\
\text { law (2) }\end{array}$ & 6 \\
\hline & Health and safety & $\begin{array}{lllll}\begin{array}{l}\text { Companies will provide a safe working } \\
\text { environment (4) }\end{array} & & & & \\
\end{array}$ & 7 \\
\hline & Fair salary & $\begin{array}{l}\text { Companies will offer a remuneration ensuring an } \\
\text { adequate standard of living (2) }\end{array}$ & 8 \\
\hline & $\begin{array}{l}\text { Association and } \\
\text { collective } \\
\text { bargaining }\end{array}$ & $\begin{array}{l}\text { Companies will ensure the right of free association } \\
\text { and collective bargaining (5) }\end{array}$ & 9 \\
\hline \multirow{2}{*}{$\begin{array}{l}\text { National } \\
\text { sovereignty }\end{array}$} & $\begin{array}{l}\text { Economic, political } \\
\text { and social rights }\end{array}$ & $\begin{array}{l}\text { Companies will observe economic and social rights, } \\
\text { including right for safe water, housing, health and } \\
\text { food }(7)\end{array}$ & 10,12 \\
\hline & Indigenous rights & $\begin{array}{l}\text { Companies will respect indigenous peoples' rights } \\
\text { (3) }\end{array}$ & 10,12 \\
\hline Corruption & Corruption & $\begin{array}{l}\text { Companies will respect national and international } \\
\text { law and refrain from corruption acts (14) }\end{array}$ & 10,11 \\
\hline \multirow{6}{*}{$\begin{array}{l}\text { Consumer } \\
\text { protection }\end{array}$} & Legislation & $\begin{array}{l}\text { Companies will observe national and international } \\
\text { legislation on consumer rights (4) }\end{array}$ & 13 \\
\hline & Health and safety & $\begin{array}{l}\text { Companies will ensure the safety and quality of } \\
\text { their products (4) }\end{array}$ & 13 \\
\hline & $\begin{array}{l}\text { Fair information } \\
\text { and education }\end{array}$ & $\begin{array}{l}\text { Companies will provide complete, truthful and fair } \\
\text { information about their products/services }(8)\end{array}$ & 13 \\
\hline & Distribution & $\begin{array}{l}\text { Companies will ensure a fair and efficient } \\
\text { distribution of their products (1) }\end{array}$ & 13 \\
\hline & Compensation & $\begin{array}{l}\text { Companies will compensate their customers in case } \\
\text { of non-compliance (2) }\end{array}$ & 13 \\
\hline & $\begin{array}{l}\text { Sustainable } \\
\text { consumption }\end{array}$ & $\begin{array}{l}\text { Companies will promote sustainable consumption } \\
(3)\end{array}$ & 13 \\
\hline $\begin{array}{l}\text { Environmental } \\
\text { protection }\end{array}$ & $\begin{array}{l}\text { Respect for the } \\
\text { environment }\end{array}$ & $\begin{array}{l}\text { Companies will conduct their activities in } \\
\text { accordance with the goal of sustainable } \\
\text { development (9) }\end{array}$ & 14 \\
\hline \multirow{3}{*}{$\begin{array}{l}\text { Provisions for } \\
\text { implementation }\end{array}$} & $\begin{array}{ll}\text { Policies } & \text { and } \\
\text { procedures }\end{array}$ & $\begin{array}{l}\text { Companies will adopt policies and procedures to } \\
\text { ensure compliance (2) }\end{array}$ & 15 \\
\hline & Value chain & $\begin{array}{l}\text { Companies will ensure compliance in their sphere } \\
\text { of influence (procurement, outsourcing, investment } \\
\text { projects) (3) }\end{array}$ & 15 \\
\hline & $\begin{array}{l}\text { Monitoring } \\
\text { enforcement }\end{array}$ & $\begin{array}{l}\text { Companies will adopt monitoring and enforcement } \\
\text { mechanisms (3) }\end{array}$ & 16,18 \\
\hline
\end{tabular}


Table 3. Analysis of the studied dimensions

\begin{tabular}{|c|c|c|c|c|c|c|c|c|}
\hline Dimension & $\begin{array}{l}\text { Formal } \\
\text { Commit }\end{array}$ & $\begin{array}{c}\text { Life, } \\
\text { Liberty } \\
\text { Security }\end{array}$ & $\begin{array}{l}\text { Labour } \\
\text { Rights }\end{array}$ & Corrup & $\begin{array}{l}\text { National } \\
\text { Sovereig }\end{array}$ & Environm & $\begin{array}{l}\text { Consumers } \\
\text { Protection }\end{array}$ & Implement \\
\hline $\begin{array}{l}\text { Mean } \\
\text { (maximum score) }\end{array}$ & $\begin{array}{l}6.33 \\
(18)\end{array}$ & $\begin{array}{l}0.91 \\
(15)\end{array}$ & $\begin{array}{c}18.77 \\
(57)\end{array}$ & $\begin{array}{l}9.8 \\
(42)\end{array}$ & $\begin{array}{l}2.2 \\
(30)\end{array}$ & $\begin{array}{l}9.33 \\
(33)\end{array}$ & $\begin{array}{l}15.25 \\
(66)\end{array}$ & $\begin{array}{l}2.91 \\
(18)\end{array}$ \\
\hline Standard deviation & 4.34 & 2.14 & 10.58 & 8.92 & 2.93 & 5 & 10.18 & 3.26 \\
\hline Std. Asymmetry & 0.8 & 6.38 & 0.35 & 0.87 & 1.37 & 0.35 & 0.2 & 5.38 \\
\hline Std. Kurtosis & -1.05 & 8.19 & -0.97 & 0.004 & 0.93 & -0.37 & -1.58 & 9.59 \\
\hline Cronbach's alpha & 0.87 & 0.83 & 0.92 & 0.92 & 0.78 & 0.83 & 0.9 & 0.86 \\
\hline Mean discrimination & 0.67 & 0.66 & 0.62 & 0.64 & 0.52 & 0.53 & 0.52 & 0.66 \\
\hline F total correlation & 0.65 & 0.42 & 0.88 & 0.81 & 0.57 & 0.71 & 0.86 & 0.62 \\
\hline Final items (initial) & $6(6)$ & $5(8)$ & $17(19)$ & $14(14)$ & $10(11)$ & $11(11)$ & $22(22)$ & $6(8)$ \\
\hline
\end{tabular}

Table 4. Differences among companies. Mean (standard deviation)

\begin{tabular}{|c|c|c|c|c|c|c|c|c|}
\hline & $\begin{array}{l}\text { Formal } \\
\text { Commit. }\end{array}$ & $\begin{array}{c}\text { Life, } \\
\text { Liberty } \\
\text { Security }\end{array}$ & $\begin{array}{l}\text { Labour } \\
\text { Rights }\end{array}$ & Corrup. & $\begin{array}{l}\text { National } \\
\text { Soverei. }\end{array}$ & Environm. & $\begin{array}{l}\text { Consumers } \\
\text { Protection }\end{array}$ & Implement \\
\hline \multicolumn{9}{|l|}{ Industry } \\
\hline Energy & $\begin{array}{c}8.25 \\
(3.81) \\
\end{array}$ & $\begin{array}{c}1.63 \\
(3.07) \\
\end{array}$ & $\begin{array}{l}24.63 \\
(9.90) \\
\end{array}$ & $\begin{array}{c}15.5 \\
(2.75) \\
\end{array}$ & $\begin{array}{c}2.75 \\
(3.45) \\
\end{array}$ & $\begin{array}{l}23.88 \\
(4.42) \\
\end{array}$ & $\begin{array}{l}14.25 \\
(3.99) \\
\end{array}$ & $\begin{array}{c}3.75 \\
(2.31) \\
\end{array}$ \\
\hline $\begin{array}{l}\text { Raw } \\
\text { materials }\end{array}$ & $\begin{array}{c}6.75 \\
(4.30) \\
\end{array}$ & --- & $\begin{array}{l}14.88 \\
(7.94) \\
\end{array}$ & $\begin{array}{c}6.25 \\
(4.13) \\
\end{array}$ & $\begin{array}{c}0.6 \\
(0.9) \\
\end{array}$ & $\begin{array}{c}6.25 \\
(5.75) \\
\end{array}$ & $\begin{array}{c}7.13 \\
(3.23) \\
\end{array}$ & $\begin{array}{c}1.50 \\
(1.69) \\
\end{array}$ \\
\hline $\begin{array}{l}\text { Consumer } \\
\text { goods }\end{array}$ & $\begin{array}{c}5.57 \\
(4.72) \\
\end{array}$ & --- & $\begin{array}{r}14.43 \\
(9.81) \\
\end{array}$ & $\begin{array}{c}6 \\
(2) \\
\end{array}$ & $\begin{array}{c}6.5 \\
(2.68) \\
\end{array}$ & $\begin{array}{r}12.86 \\
(6.31) \\
\end{array}$ & $\begin{array}{c}7.71 \\
(4.19) \\
\end{array}$ & $\begin{array}{c}3.43 \\
(5.65) \\
\end{array}$ \\
\hline Finance & $\begin{array}{c}5.11 \\
(4.78) \\
\end{array}$ & $\begin{array}{c}1.89 \\
(2.71) \\
\end{array}$ & $\begin{array}{c}18.44 \\
(12.44) \\
\end{array}$ & $\begin{array}{c}11 \\
(2.5) \\
\end{array}$ & $\begin{array}{c}9.78 \\
(2.77) \\
\end{array}$ & $\begin{array}{c}15.33 \\
(11.38) \\
\end{array}$ & $\begin{array}{c}8.00 \\
(5.29) \\
\end{array}$ & $\begin{array}{c}2.78 \\
(2.54) \\
\end{array}$ \\
\hline$I T$ & $\begin{array}{c}2.00 \\
(2.83) \\
\end{array}$ & $\begin{array}{c}0.50 \\
(0.71) \\
\end{array}$ & $\begin{array}{c}21.00 \\
(12.73) \\
\end{array}$ & $\begin{array}{c}14 \\
(4.5) \\
\end{array}$ & $\begin{array}{c}8.5 \\
(6.36) \\
\end{array}$ & $\begin{array}{c}20.50 \\
(12.02) \\
\end{array}$ & $\begin{array}{l}11.00 \\
(4.24) \\
\end{array}$ & $\begin{array}{c}4.50 \\
(3.54) \\
\end{array}$ \\
\hline \multicolumn{9}{|c|}{ Countries of operation } \\
\hline$O E C D$ & $\begin{array}{c}4.20 \\
(4.02)\end{array}$ & $\begin{array}{c}1.40 \\
(3.13) \\
\end{array}$ & $\begin{array}{c}15.20 \\
(14.10)\end{array}$ & $\begin{array}{c}5 \\
(8.62) \\
\end{array}$ & $\begin{array}{c}1.2 \\
(1.3) \\
\end{array}$ & $\begin{array}{c}15.00 \\
(11.18)\end{array}$ & $\begin{array}{c}7.40 \\
(4.72) \\
\end{array}$ & $\begin{array}{c}2.20 \\
(2.68) \\
\end{array}$ \\
\hline $\begin{array}{l}O E C D \text { and } \\
\text { non-OECD }\end{array}$ & $\begin{array}{c}2.60 \\
(2.41) \\
\end{array}$ & $\begin{array}{c}0.20 \\
0.45) \\
\end{array}$ & $\begin{array}{c}13.40 \\
(11.33)\end{array}$ & $\begin{array}{l}11.17 \\
(8.7) \\
\end{array}$ & $\begin{array}{c}2.6 \\
(3.16) \\
\end{array}$ & $\begin{array}{r}13.40 \\
(8.44) \\
\end{array}$ & $\begin{array}{c}6.60 \\
(5.46) \\
\end{array}$ & $\begin{array}{c}2.00 \\
(2.12) \\
\end{array}$ \\
\hline \multicolumn{9}{|c|}{ Foreign stock markets } \\
\hline Non-listed & $\begin{array}{c}5.76 \\
(4.13) \\
\end{array}$ & $\begin{array}{c}0.38 \\
(1.35) \\
\end{array}$ & $\begin{array}{l}16.41 \\
(9.85) \\
\end{array}$ & $\begin{array}{c}1.70 \\
(2.69) \\
\end{array}$ & $\begin{array}{c}5 \\
(2.82) \\
\end{array}$ & $\begin{array}{l}13.24 \\
(9.43 \\
\end{array}$ & $\begin{array}{c}8.59 \\
(4.83) \\
\end{array}$ & $\begin{array}{c}2.38 \\
(3.16) \\
\end{array}$ \\
\hline Listed & $\begin{array}{c}8.40 \\
(5.77) \\
\end{array}$ & $\begin{array}{c}4.00 \\
(3.32) \\
\end{array}$ & $\begin{array}{l}29.80 \\
(6.30) \\
\end{array}$ & $\begin{array}{c}7.62 \\
(6.69) \\
\end{array}$ & $\begin{array}{c}24.4 \\
(5) \\
\end{array}$ & $\begin{array}{l}25.20 \\
(2.49) \\
\end{array}$ & $\begin{array}{c}14 \\
(2.55) \\
\end{array}$ & $\begin{array}{c}6.20 \\
(0.45) \\
\end{array}$ \\
\hline \multicolumn{9}{|c|}{ Market capitalization } \\
\hline Low & $\begin{array}{c}4.9 \\
(3.8) \\
\end{array}$ & $\begin{array}{c}0.38 \\
(1.53) \\
\end{array}$ & $\begin{array}{l}14.1 \\
(9.5) \\
\end{array}$ & $\begin{array}{c}6 \\
(6) \\
\end{array}$ & $\begin{array}{c}1 \\
(1.74) \\
\end{array}$ & $\begin{array}{c}12 \\
(9.2) \\
\end{array}$ & $\begin{array}{c}7.23 \\
(4.97) \\
\end{array}$ & $\begin{array}{c}1.76 \\
(1.75) \\
\end{array}$ \\
\hline Medium & $\begin{array}{c}8.33 \\
(4.21) \\
\end{array}$ & $\begin{array}{c}1.22 \\
(2.95) \\
\end{array}$ & $\begin{array}{l}22.66 \\
(7.95) \\
\end{array}$ & $\begin{array}{c}14.1 \\
(9.8)\end{array}$ & $\begin{array}{c}2.71 \\
(2.63) \\
\end{array}$ & $\begin{array}{l}16.44 \\
(8.43) \\
\end{array}$ & $\begin{array}{l}11.77 \\
(4.41) \\
\end{array}$ & $\begin{array}{c}4.44 \\
(4.92) \\
\end{array}$ \\
\hline High & $\begin{array}{c}7.75 \\
(6.45) \\
\end{array}$ & $\begin{array}{c}3 \\
(1.82) \\
\end{array}$ & $\begin{array}{l}31.25 \\
(6.65) \\
\end{array}$ & $\begin{array}{c}22.5 \\
(3.11) \\
\end{array}$ & $\begin{array}{c}7.25 \\
(2.63) \\
\end{array}$ & $\begin{array}{c}27.5 \\
(3)\end{array}$ & $\begin{array}{l}15.25 \\
(3.20) \\
\end{array}$ & $\begin{array}{c}5.75 \\
(1.26) \\
\end{array}$ \\
\hline \multicolumn{9}{|c|}{ Sustainability Indexes } \\
\hline Listed & $\begin{array}{c}2.6 \\
(2.6)\end{array}$ & --- & $\begin{array}{c}8.1 \\
(6.37) \\
\end{array}$ & $\begin{array}{c}3.3 \\
(4.44) \\
\end{array}$ & $\begin{array}{c}0.43 \\
(0.53) \\
\end{array}$ & $\begin{array}{c}8.3 \\
(8.41) \\
\end{array}$ & $\begin{array}{c}4.4 \\
(3.06) \\
\end{array}$ & $\begin{array}{c}0.9 \\
(0.99) \\
\end{array}$ \\
\hline Non-listed & $\begin{array}{c}7.62 \\
(4.16)\end{array}$ & $\begin{array}{c}1.29 \\
(2.56)\end{array}$ & $\begin{array}{l}22.66 \\
(8.78)\end{array}$ & $\begin{array}{l}12.91 \\
(8.8)\end{array}$ & $\begin{array}{c}2.86 \\
(3.16)\end{array}$ & $\begin{array}{l}17.79 \\
(8.97)\end{array}$ & $\begin{array}{l}11.45 \\
(3.99)\end{array}$ & $\begin{array}{c}3.79 \\
(3.45)\end{array}$ \\
\hline
\end{tabular}




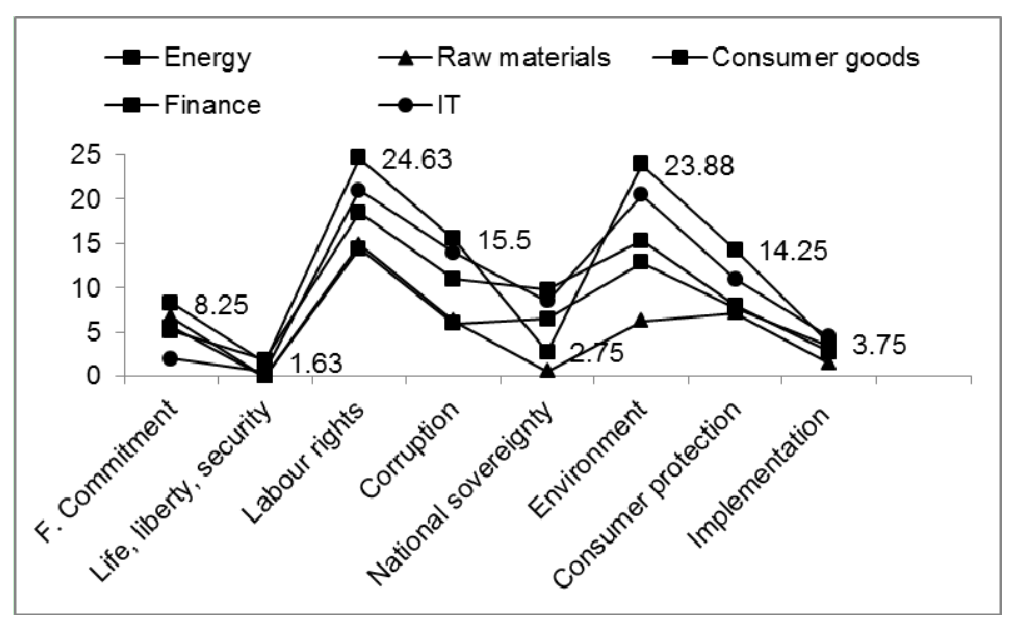

Figure 1. Differences by industry

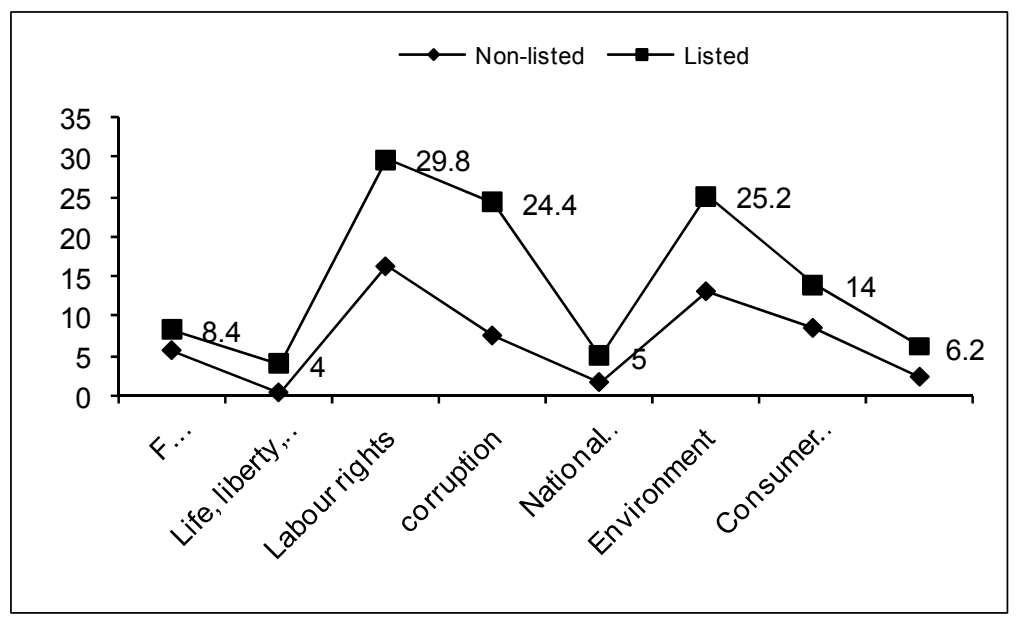

Figure 2. Differences between listed and not listed in foreign stock markets

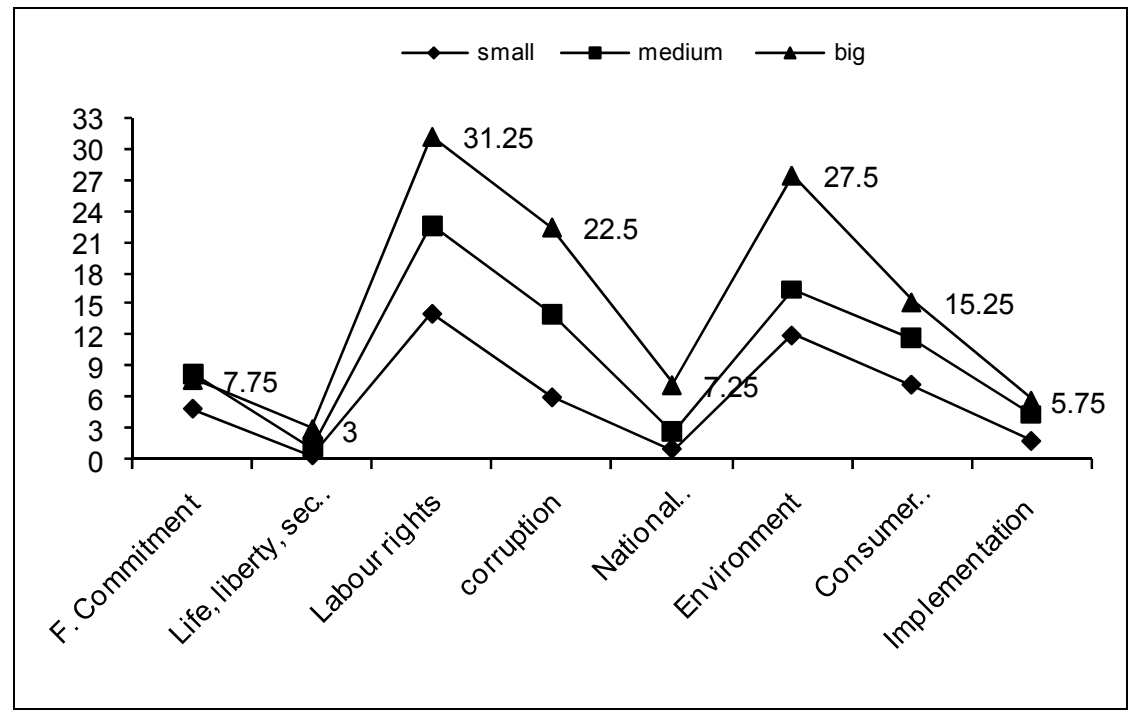

Figure 3. Differences by market capitalization 


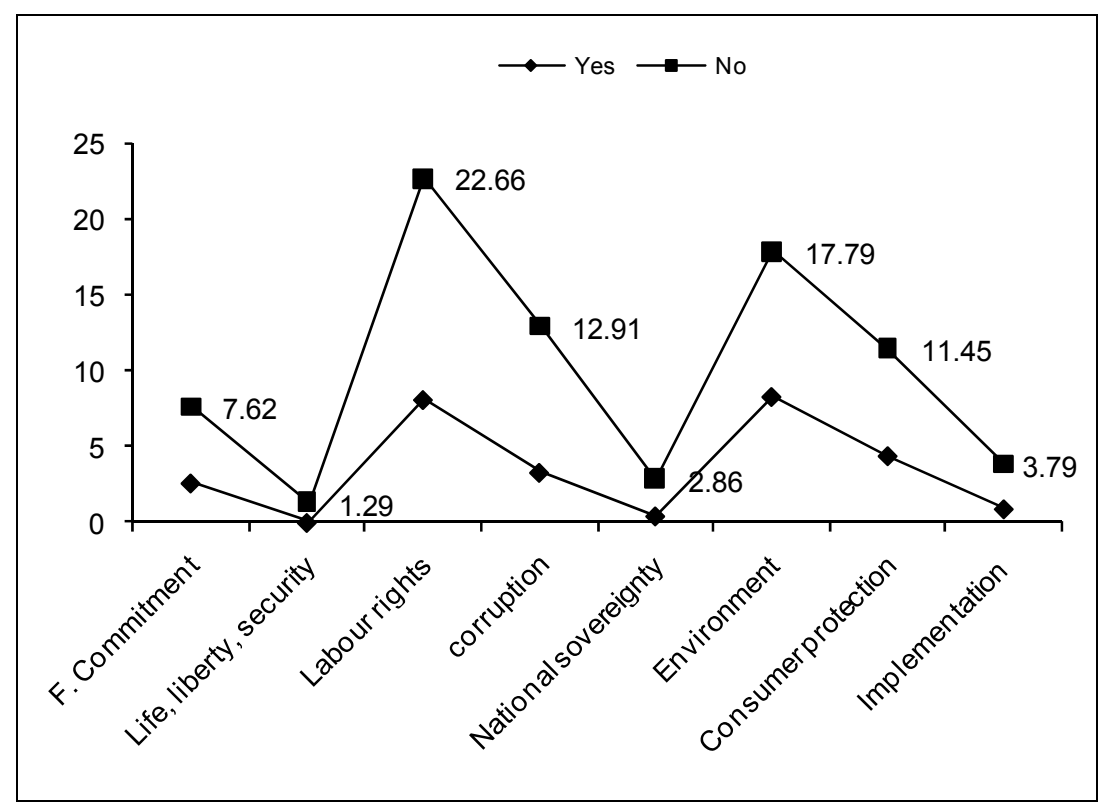

Figure 4. Differences by CSR indexes 